\title{
Easter Songs in the Russian Folk Tradition: \\ The Case of the Smolensk Region \\ Svetlana Latysheva
}

The present article is devoted to Russian folk terminology and the lexical items connected to Easter songs and their performance which have been attested in the Smolensk region. A wide range of names exists in the folk song tradition. They vary not only from region to region but also from song to song and, even within one region, the same song can have different names. I will try to offer plausible explanations for this phenomenon. My work is based on archival materials located in the Research Laboratory for the Study of Traditional Musical Cultures in the Gnesin Musical Academy in Moscow. Only the verbal texts and songs of the Easter cycle will be discussed. They are generally performed in the period starting at Easter and ending on Ascension Day. The songs have been recorded over the last few decades by folklore expeditions to the Smolensk region.

Since the singers are called by different names, it may be revealing to trace the origin of the names. Performers were called laudatory singers or "volochebniki." This term has several variations: "volochiobniki," "volochebniki," "volochebnichki," and "volochebnye ispolniteli." It appears that these variants were used within the Smolensk region as local derivatives and that they were applied to the performers of a particular folk song genre - "volochebmye pesni." Although folk etymology connects this term to "volshebrye songs" (miraculous songs) [Nikol'sky, 1931: 270], I think this is an improbable explanation because these songs were basically laudatory in nature. The verses praising a household owner contain greetings and special wishes for wealth, security, or good crops; there is no direct invocation of magic.

The songs called "volochebnitskie," "volochebniki," or "volochebnye" are more properly, though distantly, related to praise songs (velichal'nye pesni) which can contain seasonal greetings, as well as a variety of festive greetings. The greetings were addressed primarily to Christ and so the songs in question were also called "christoslavskie pesni" (songs glorifying Christ), and "stikh" (verse). "Verse" was a common term for songs performed in churches during the liturgy, as well as outside the church during funerals, Lent, and on other occasions. The term "verse" was applied, for instance, to the song "Christ himself was walking on the land." The text of this song is frequently encountered alongside other spiritual verses (dukhovmye stikhi or pesni). Praise songs are distinct from the songs under examination here because they have a cumulative structure: after the main text, performers sing the so called addition, which contains a request for a gift or donation. A number of phrases are used to describe the performance itself. These include: "to walk under the window" (vokno), "to walk with songs" (to go with songs), "to go 
Christing" (asking in the name of the Christ), "to glorify (laud) Christ." Other phrases deal more with genre terminology: "to sing volochebniki," "to play volochebnitskie," or "to play music." Terminology also derives from playing folk musical instruments and from the act of singing: "to sing" (spevat', podpevat', lalynkat').

The well known Easter laudatory song "Christ is risen" (tropar) is performed from Easter to Ascension Day, that is, for forty days. Performance of the song is reflected in such terms as "to weep for Christ." "to go weep for Christ," to sing "Christ is risen" for cows (when cattle are driven to pasture), "to sing two parts without interruption," "to sing in two groups" (perelagi - performance by several groups in alternation). The terms to sing "naperialiv" and "naperiamenu" designate a rare type of performance when both kinds of musical text are sung together, that is, volochebryie and laudatory songs, are performed in turns. This sort of performance can occur during a walk around the rye field on Ascension Day and when it does, the two types of songs are sandwiched together and sung alternately.

The first thing that one notices in the folk terms used to describe the singing of volochebrye songs is that they emphasize both the action and the process of moving: e.g. "to go Christing." This is a feature that can be shared with laudatory songs, the performance of which can be reflected in phrases such as "to go to weep for Christ." Although both sets of terms emphasize action, there is nonetheless a genre distinction: laudatory songs are usually "cried, "while volochebnyi songs are never cried but "just sung." The term "to cry" (podkriknut) can be used with volochebryi songs, but only in regard to the song's refrains which are also designated by the terms "to second" (podpevat', pripevat '). Perhaps this can be explained by the fact that certain volochebryi song refrains, such as the ones in the texts "Christ is risen, God's son, " and "Christ, God's son, is risen," are similar to the text of the laudatory song "Christ is risen."

In Russian folk tradition, the Easter period is permeated with a plethora of musical texts. They are attached to the main festive days: Easter, Radunitsa (ninth day after Easter), Yegor's Day (St. George's Day), Mikola's Day (St. Nicholas' Day), Day of the Mymh-Bearing Women (Easter Monday), and Ascension Day. During this period, songs from other genres could be sung alongside volochebryi songs and "Christ is Risen," the main laudatory song of Easter. Depending on the region, volochebmyi songs could be sung during the first two or three days of Easter, or during the entire Easter week. In some regions, they were sung on Yegor's Day and Mikola's Day. Rarer still were performances on Ascension Day. The other genres performed during the Easter period include: dukhouskie songs (Holy Spirit Day songs), dance songs, and lyric songs which were attached to these specific dates. Thus, on Easter, "spring" songs and "udovskie" (widows' songs) could be sung. Songs about the month of May (songs with the refrain "maiu-maiu" could be sung on Radumitsa. "Yegor'evskie" (Yegor songs), "dukhovskie," "summer," "karagodnye" (circle dance songs), "drinking" songs, and "pripevki" (dueling refrains) were performed on 
St. Yegor's Day, and "mikol'skie" (Mikola songs) - on St. Nicholas' Day. "Spring", "summer," "bad," "obscene," "golosmye" (vocal songs), "usiakie" (any song that just came to mind), and chastushki (ditties) were sung on the Day of the Myrrh-Bearing Women; "maiskie" and "assorted" songs were sung on Ascension Day. We should note in passing that there was a terminological distinction between singing "special" songs and "just making merry" which was used to refer to the singing of any old song. Also of note is the fact that, in the Smolensk tradition, the volochebmye songs performed on the Days of Yegor (St. George) and Mikola (St. Nicholas) were addressed, not to a household owner or to anyone from his family, but to Yegor and Mikola. The same melody, but with different words, except for the fixed refrain "Christ is risen, God's son, " were also called "egorevskie" and "mikolskie" songs.

A large number of terms designate the performance of the various song texts. The following terms are common: "to wail," "to cry," "to sing about mai," and "to lament" ("priachitat"). The last of these is particularly associated with the performance of laments on Radunitsa. The performers call what they do on Yegor's Day (St. George) "to sing the Yegor," "to sing for the cows," "to play Yegor," "to play songs," "to play dukhovskie." Performing the songs that go with the Day of St. Nicholas (Mikola's Day) is called "to sing for horses, " while singing the songs that are appropriate to the Day of the Myrrh-Bearing Women is called "to play songs" and "to cry Maiu-maiu." "To sing the cornfield" (the name of the song beginning with the words "Holy Spirit and Trinity") and "to sing the Spirit" are the terms associated with performing songs on Ascension Day. It should be noted that folk speech always uses the term "to sing" when referring to "holy" and "divine songs" and to the spiritual verses performed during Lent or the Great Fast preceding Easter. By contrast, they say "to read" when they wish to indicate the performance of prayers associate with written texts.

In addition to the songs discussed above, other folk texts characterized the Easter period. Incantations are particularly well attested in the archive used for this article. I have recordings of incantations for Palm Sunday, Holy Thursday, and Yegor's Day. The term for the recitation of incantations is usually "to murmur" while the incantations themselves are called "priskazka" (tale introduction) and "pribaiutka" (wisecrack). One example of an incantation is a text "murmured" by the inhabitants of the village Krapivna in Roslavl district when they were driving cattle out to pasture for the first time (usually on Yegor's Day):

Vasii-Hvanasii,

Show my cow a path (putinku),

Feed her with a silky grass,

Give her honey dew to drink!

Another example is the following:

Good Master, accept my beast 
With hospitality and with a good word.

Incantations could be "cried" as well as "murmured" and, on Holy Thursday, the inhabitants of the same village took a jelly-drink to a shed, left it there, and "cried":

Bear-Bear, come eat the jelly!

Don't touch our oats, buckwheat, or rye,

Don't eat our oats, don't smash our rye,

Don't trample the buckwheat,

And come eat the jelly with us!

One could say "to request with conversations" when speaking about incantations. For example, while the cattle were being driven to pasture for the first time, the inhabitants of the village Saveevo in the same district "requested with conversations":

"Victorious George, (St. George, you who are victorious in battle) take care of our cattle!" Magical verbal acts that were not incantations included the practice of repeating "Christ is risen" three times. This could be done over crops or livestock. The verbs used for such actions included to "khristosovat" the cows," to "pokhristosovatsia" with the cattle," and to "khristosovat" the rye.

Thus one can conclude that there is a difference between the terms designating the performance of musical and verbal texts durng the Easter period. There is a clear-cut demarcation in terminology between the volochebryi songs on one hand, and the incantations and the songs of the other genres, including the laudatory song "Christ is Risen," on other. Folk performers say "to cry" when they speak of laudatory song performance (to cry Christ) and when they refer to the uttering of incantations (to cry the Bear and to cry the Deceased). They also use "cry" when referring to the so-called "maiskie" songs ("to cry Maiu-maiu"). By contrast, when it comes of the volochebnye songs that are the focus of this article, their preferred term is "to sing." The terminology designating song performance shows that the song types are distinct in folk culture. Although the various songs types coexist with a single holiday period, they are nonetheless opposed to one another, at least in the traditional culture of the Smolensk region. One interesting aside may serve as a concluding remark: in the folk material under examination here, the term "to cry" designates the performance of a wide range of folk phenomena, both musical and verbal.

N. Nikolski. Mitolegiia i abradavsts valachobnukh pesen [Mythology and rituals laudatory songs]. vyp. 1. Minsk, 1931.1 